CI

11,4

380

Received 18 November 2010 Accepted 31 May 2011

\section{Client's championing characteristics that promote construction innovation}

\author{
Kushan Kulatunga \\ Corderoy, Manchester, UK, and
}

Udayangani Kulatunga, Dilanthi Amaratunga and Richard Haigh School of the Built Environment, The University of Salford, Salford, UK

\begin{abstract}
Purpose - Clients or users of products, processes or services are currently being identified as potential sources of innovation in construction. There are concerns about the degree of innovation within the construction industry, despite having potential to be innovative. The role that can be played by the construction client to promote innovation in the industry is well documented. However, lack of knowledge on the desirable characteristics of the construction client was identified as one of the barriers for the construction client to be an effective innovation promoter. Accordingly, the purpose of this paper is to evaluate the characteristics of the construction client that promote innovation.

Design/methodology/approach - Multiple holistic case studies were used as the research strategy and semi-structured interviews were used as the principal data collection technique. Code-based content analysis and cognitive mapping were used to analyse the interviews. Data analysis was supported by two computer-aided softwares, NVivo and Decision Explorer.

Findings - Clients can increase the efficiency of work carried out towards the construction process, stimulate team dynamics, and team action through the championing characteristics, which in turn can strengthen the innovation process that lead to the innovative product. Being a team player, promoting respect for people, and knowledge and information dissemination are identified as constituents of the championing characteristics of clients that promote innovation in construction projects. The personal skills of clients such as competence, value judgement, flexibility, and self-motivation will energise the success of the championing characteristics.
\end{abstract}

Originality/value - The client characteristics identified from the study widen the knowledge base of the client to successfully engage in construction innovation.

Keywords United Kingdom, Construction industry, Innovation, Roads, Bridges, Client

Paper type Research paper

\section{Introduction}

Innovation is defined as the effective generation and implementation of a new idea which enhances overall organisational performance (Sexton and Barrett, 2003a, b; Barrett and Sexton, 1999). Innovation may entail the implementation of significant new processes, products or management approaches in order to increase efficiency (Seaden, 2003). The construction industry attracts both criticism (Reichstein et al., 2005; Blayse and Manley, 2004) as well as praise (Seaden and Manseau, 2001; Pries and Janszen, 1995) for its level of innovation. It is stated that construction lags behind the innovativeness of the manufacturing and service sectors (Reichstein et al., 2005). In contrast, Pries and Janszen (1995) stated that engineering and construction projects are inherently innovative. The project base nature of the construction industry makes every project unique thus there is a significant opportunity and tendency for new approaches. Building practitioners
Construction Innovation

Vol. 11 No. 4, 2011

pp. $380-398$

(C) Emerald Group Publishing Limited 1471-4175

DOI $10.1108 / 14714171111175873$ 
and their clients have often interpreted these new approaches as innovative behaviour (Seaden and Manseau, 2001).

To reap the benefits of innovation towards the construction industry, the industry is in need of a "champion" who can coordinate efforts for the successful exploitation of innovation potentials (Nam and Tatum, 1997). In the search for a champion to drive the construction industry, significant attention is paid on the potential role of the construction client (Lim and Ofori, 2007; Egemen and Mohamed, 2006; Manley, 2006; Harty, 2005; Blayse and Manley, 2004; Gann and Salter, 2000). Further, high-profile reports produced within the UK such as Rethinking Construction: Report from the Construction Task Force (Egan, 1998) and Constructing the Team (Latham, 1994) highlighted the importance of the client's role within the context of construction innovation. Egan (1998) further supported the argument and claimed that the clients should not only participate, but should take the leadership to drive construction innovation. There are research findings suggesting a correlation between client's activities and innovation in the construction process (Nam and Tatum, 1997). This shift in focus is also being confirmed by the trends in innovation in other sectors as the understanding of innovation changes from a supply side driven simple process to a complex process involving multiple sources (DIUS, 2008). Further, there is compelling evidence from other industries to confirm the influence that a client can exert on the generation of innovation (Maklan et al., 2008; Mackay et al., 2000; Martin et al., 1999; Fullerton and West, 1996; Gardiner and Rothwell, 1985).

The existing literature and the recommendations of leading authors create a case for the client's active involvement in the process of construction innovation. Nevertheless, lack of research addressing the characteristics of construction client that influence construction innovation in detail is evident. In addition, evidence of misguided action by clients which hamper innovation (Hillebrandt, 2000; Ball, 1988), suggests a lack of understanding about the activities or roles that a client should carry out to improve innovation in construction. Hence, the need for investigating the characteristics of clients that could positively influence the innovative culture of the construction project needs to be investigated (Dulaimi, 2008). With the aim of improving the role of the construction client in promoting innovation, this paper evaluates the championing characters of a large public sector client. The paper first discusses the nature of construction innovation with particular reference to the importance of construction client towards successful innovation. This is followed by the research methods adopted for the study. Main findings and discussion of the study are presented next.

\section{Nature of construction innovation}

Despite being a dominant part of the economy, the construction industry is criticised for lagging behind in relation to levels of innovation compared to other industries (Reichstein et al., 2005), thus holding back the overall potential of the whole economy. The statistical data show that the percentage of "innovation active enterprises" in the construction industry is 5 per cent lower when compared to the UK benchmark which is 60 per cent (Department for Business Enterprise and Regulatory Reform, 2007). Even though the unique conditions faced by the construction industry due to their project-based nature, provide the potential to be innovative, uniqueness itself can also be a hindrance for construction innovation (Pries and Janszen, 1995). Owing to the unique conditions imposed by the temporary site-based operations such as; topography,
Construction innovation

381 
CI

11,4

382

other members of the temporary project team and one off clients, the contractor has little to gain from being innovative, other than optimisation of their own process (Pries and Janszen, 1995). When this uniqueness becomes combined with the particularly long-life span of the constructed products, it can create hostility towards innovation as it compels the client to stick to known methods rather than being radically innovative (Blayse and Manley, 2004).

The conservatism attached to the construction industry was also confirmed in the study conducted by Dulaimi et al. (2005) where some participants expressed concern that innovators who may go beyond established organisational policies and practices might trigger an increased risk on the project objectives. In this context, securing the support of the project parties may become increasingly challenging. Since risk of failure is higher in construction, trial-and-error approach is not acceptable (Nam and Tatum, 1997). In unique projects, economies of scale rarely exist and knowledge gains are rarely transferred (Pries and Janszen, 1995). There are observations to suggest the effect of uniqueness on innovation depends on the nature of the projects. In the study on use of virtual reality in the construction industry, Whyte (2003) identifies that small projects with design re-use and large unique projects promote the use of virtual reality innovatively. When the company is small and work is repetitive, it is possible to harvest higher returns with comparatively small investment in technology. On the other hand, large complex projects make room for innovation to overcome the associated practical problems.

\section{Clients' importance in driving innovation in the construction industry}

Early research identified the client as a member of the construction process who can stimulate the innovation potential to reap benefits (Roger, 2008; Manley, 2006; Harty, 2005; Gann and Salter, 2000). According to Lu (2008), construction client can directly influence explorative innovation and indirectly influence exploitative innovation in small construction firms. Manley (2006) calls for innovation competent clients to maximise the construction industries innovation potential. Nam and Tatum (1997) and Roger (2008) claim that technological progress in construction requires the clients' involvement and leadership. In most cases, the willingness of the client for risk sharing, commitment to innovation and leadership in project planning and execution seemed to be critical for the success of the innovation process. In addition, the position of client as the organiser of the project appeared to influence the project environment by encouraging more integration among project participants. In Fairclough's (2002) report, the obligation of the government as the major client of the construction industry towards its development is highlighted. Within this scenario, the construction client is looked upon as a person (or organisation) that can coordinate and direct the construction process towards innovation. The study carried out by Roger (2008) on large engineering projects revealed that construction clients acts as innovation drivers by ensuring projects are economically viable, technically functional and socially acceptable. Egemen and Mohamed (2006, p. 611), emphasise the need for change in the attitude towards the construction client by stating "the traditional assumption that the client only need projects which are completed within budget, on schedule and with a reasonable quality should start to change". Egan (1998) agrees that clients should take a leading role and asserts that impetus for change within the construction industry must come from major clients.

The research of Lim and Ofori (2007) confirmed that the more dominant role of clients in controlling, the pace of innovation or change is playing important role in stimulating 
contractors to search for new ideas. It could be argued that clients naturally hold an influential position in construction project organisations, and are thus able to raise organisational expectations, which exert a primary pressure upon the organisations' tendency to innovate. The research of Nam and Tatum (1997) suggest that there might be a close relationship between the client's technical competence and project innovation. The competence of the client encourages active participation in the project development or at least a better understanding of technical matters for timely approval of innovative ideas. Furthermore, their study revealed the existence of positive correlation between client's technical competency and commitment and innovation in the project. Historically, it is evident that the drive for innovation in construction often stems from demand pull. For example, demand for new types of building has been stimulated by changing life-styles and urbanisation. Demanding clients have driven suppliers to meet tough challenges (Manley, 2006). Harty (2005) also agrees with this view and states that pressures of client demand and expectation led the construction industry to become involved in innovative work.

Even though there is a reason for promoting a more prominent place for the client in the implementation of construction innovation, the view of client leadership in construction is not totally supported by all (Hillebrandt, 2000; Green, 1999), or at least not regarded as industry-wide truth. Hillebrandt (2000) points out that although both the Egan (1998) and Latham (1994) reports speak of the industry as though they were dealing with the totality, in fact much of the discussion and most of the recommendations are applicable only to part of the industry that is constructing large new projects, which are generally lead by large repeat clients. Furthermore, there is research, which identifies the client as a key inhibitor, which again identifies the influence that can be exerted, by the client. Ivory's (2005) study revealed the adverse effect on innovation due to the desire of the clients to avoid risk associated with innovation. In his study, client actively sought to control innovation to ensure that it did not threaten the financial constraints (Ivory, 2005). Ivory (2005) argues that the client's intention to use established methods, processes and procedures rather than taking risks with new innovation hinders the advancement of technological frontiers which can cause adverse effects on the industry in the long term. The study of Ivory (2005) also confirms the observation of Ball (1988) who found that many construction firms avoided the introduction of novel processes owing to conservative consumers and clients who make it difficult for them to be innovative.

The disagreement on client role in promoting innovation does not mean that the construction client does not have a place in innovation. The client of a construction project is the initiator of most of the projects by identifying novel requirements to be delivered by the construction sector (Blayse and Manley, 2004). The client is the base around which other parties communicate, collaborate, make important and innovative decisions, and implement the project (Nam and Tatum, 1997). Further, due to the complexity of innovation, the nature, different types, and categories of construction clients, it is unwise to claim all groups of clients carrying out similar roles in different types of innovations (Egbu, 2008). Lim and Ofori (2007) conclude that clients, who are the initiators and the investors of the construction process, have a direct impact on the construction firms' decisions to innovate.

\section{Construction} innovation

383 
CI

11,4

384

\section{Research methodology}

Research approach and case selection

Case study research approach was selected to investigate the client's characteristics that influence innovation in construction projects. The "client's championing characteristics in innovation" was selected as the unit of analysis within the boundary of innovative construction project. Accordingly, two case studies were selected for this study. In multiple case study design, case selection had to be done purposefully to predict similar results or contrasting results for predictable reasons (Yin, 2003). Eisenhardt (2002) attests to this by stating that case study research relies on theoretical sampling rather than statistical sampling. Under the theoretical sampling, the cases were selected based on a theory rather than based on statistical selection or random selection. Silverman (2001) identifies subtle variation to theoretical sampling which is named purposive sampling where the purpose behind the case selection is not theoretically defined. This "purposive approach" in case selection enables the researcher to select cases that demonstrate characteristics in which they are interested (Silverman, 2001). The authors acknowledge the importance of theoretical selection of cases rather than the statistical or random selection and argue that for this study on "client's characteristics that influence construction innovation" it is necessary to select a case from a context where innovation is present or from a context where innovation is not present due to predictable reasons. However, the option of "context with innovation is present" was selected for this study, as it provides comparable scenarios without the need for isolating other variables to achieve the objectives of the research.

During the initial case study screening process, the attention was given to construction projects with partnering contracts to cater the requirement of increasing the possibility of finding a well-committed client in an innovative setting. Partnering is being recommended as a means of driving innovation and incremental innovation in the UK construction industry (Fortune and Setiawan, 2005; Kumaraswamy and Dulaimi, 2001; Bresnen and Marshall, 2000; Egan, 1998). Further, long-term collaborations can foster better understanding of fellow team members and their competencies that can improve mutual trust among members (Himes, 1995). Improved mutual understanding will reduce the adversarialism and will increase the ability of parties to be honest brokers of innovation through better integration and cooperation (Bresnen and Marshall, 2001). Further, long-term relationships resulting in partnering can eliminate learning curves which are also an advantage for innovation as it addresses the issue of lack of knowledge dissemination (Bresnen and Marshall, 2000). Therefore, it can be argued that such an environment provides the client with a better opportunity to participate more actively in the innovation process; thus, there is a greater scope to study and reveal hidden knowledge regarding client's characteristics that influence innovation.

From the partnering setting, four infrastructure projects where prominent innovations have taken place were initially selected. The core innovative areas of the selected projects were related to a bridge pier construction, drainage system development of a highway and two highway resurfacing projects. These four projects were selected based on the discussions had with the client organisation regarding the level of innovation taken place within projects. Project managers from each project were briefly interviewed to access the data richness and the feasibility of each case study. Following this screening, the list was shortened to two, where the richest and most accessible data were available (brief descriptions about the selected two projects 
are given in the section below). Further, consideration was also paid to the practical constraints imposed; such as time and resources in the case study process.

Case study descriptions

Case $X$. Case study $\mathrm{X}$ is about the execution of an innovative repair solution to a condemned central pier of a bridge in the North-West region of the UK. The project team in the case study was expected to demolish and reconstruct the bridge pier as per the recommendations of an external party. Owing to the possible disruption to traffic that would be caused by the reconstruction, the project team sought other innovative solutions to the problem. Through extensive value management and value engineering processes, an innovative repair solution to the existing bridge pier using advanced concrete repair and cathodic protection systems was developed. By challenging the established expectation of bridge pier reconstruction, the project team managed to complete the project saving approximately $£ 2$ million on the original budget allocation.

Case $Y$. Case project $Y$ is a development of a resurfacing scheme on a busy highway in the North-West region of the UK. The project was initiated to find an innovative solution to the problem of rainwater accumulation on the carriageway. The solution developed was the development and installation of a rolling crown diagonally across the carriageway to increase the gradient of the surface to facilitate quicker rainwater runoff. The project team in case $\mathrm{Y}$ was forced to develop a solution, which could be constructed without reducing the traffic flow capacity of the road. At the design stage, the professional participants went through an intense process to develop the correct gradients, complementary traffic management and work programme to allow the construction the rolling crown within the imposed constraints.

\section{Data collection and analysis}

Semi-structured interviews were used as the main method of data collection due to their ability to facilitate an in-depth inquiry into the issues. Table I shows the details of the interviews carried out. The semi-structured interviews within the selected cases were conducted in two stages. In stage one, identified participants to the innovation except the clients were interviewed to gather information related to the client's role in innovation and to identify "how did the clients behaved" and "what are the issues". The interviews were kept open ended to the maximum possible extent to allow the interviewees to feel free to express their views. In stage two, the clients were interviewed.

\begin{tabular}{ll}
\hline Case study & Designation \\
\hline Case X & Client (representative from the client's organisation) \\
& Project manager \\
& Designer 1 \\
Case Y & Designer 2 \\
& Client (representative from the client's organisation) \\
& Project manager \\
& Construction manager \\
& Specialised sub-contractor-surfacing
\end{tabular}

$$
\text { interviewees to feel free to express their views. In stage two, the clients were interviewed. }
$$

\section{Construction innovation}

385

Table I. Details of the interviewees 
CI

11,4

386
Stage-two interviews were more on the themes identified with the emphasis on "why those things happened" from the client's perspective. However, at the same time, care also had been taken not to restrict new themes or concepts from emerging. This process enabled the researcher to gather an understanding of issues from at least two distinctive perspectives as well as to triangulate findings to arrive at firm findings. All the interview transcripts were tape-recorded and manually transcribed.

Two complimentary data analysis techniques, code-based content analysis and cognitive mapping were used for data analysis. Code-based analysis is a process for identifying concepts/themes from the set of data and categorising them under different names or labels (Bernard, 2000). Cognitive mapping is recognised as a method used for structuring and analysing ideas and causal relationships between themes. Using this technique, a hierarchical network of ideas can be developed which helps to explore the relationships between them and to make them explicit (Brightman, 2004, 2003; Eden, 1992). Accordingly, code-based content analysis was used to identify themes from the interview transcripts whilst cognitive mapping technique to display causal relationships among identified concepts/themes.

To derive the codes, a hybrid approach comprising of both deductive (generation of themes with the support of literature and assigning relevant concepts from a set of data) and inductive coding (generation of themes from the data itself) was used to obtain a structured yet more comprehensive list of codes (characteristics of construction client that influence innovation). To increase the reliability of the study, coding was performed by two authors separately. The codes that were identified as significantly different were revisited until an agreement was obtained by the two authors.

The study was supported with two computer-aided software namely NVivo and Decision Explorer. To perform the analysis, the interview transcripts were uploaded to the NVivo software and carefully scrutinised with the aim of identifying concepts related to characteristics of client that influence construction innovation. Subsequently, such identified concepts were assigned with a code to reflect the client characteristic (refer Figure 1 for the NVivo structure).

After identifying the main codes related to the research question using NVivo software, they were imported to Decision Explorer software to create cognitive maps for each client characteristic (a sample is shown in Figure 2). The numbers indicated in the decision explorer diagrams are random numbers and do not have any relevance to the results.

Reliability and validity of the research were maintained throughout the study to ensure quality of the study. Quality criterion used for the study is given in Table II.

\section{Findings and analysis}

This section provides information on the characteristics of the clients that influenced construction innovation in the case studies investigated.

\section{Clients being proactive}

The proactive involvement and commitment of the client was identified as important for effective innovation in construction projects. Project manager of project $\mathrm{X}$ confirmed the proactive participation of the client; "the client was there in all of these (important meetings, etc.) and contributed to all of these". Designer of project X 


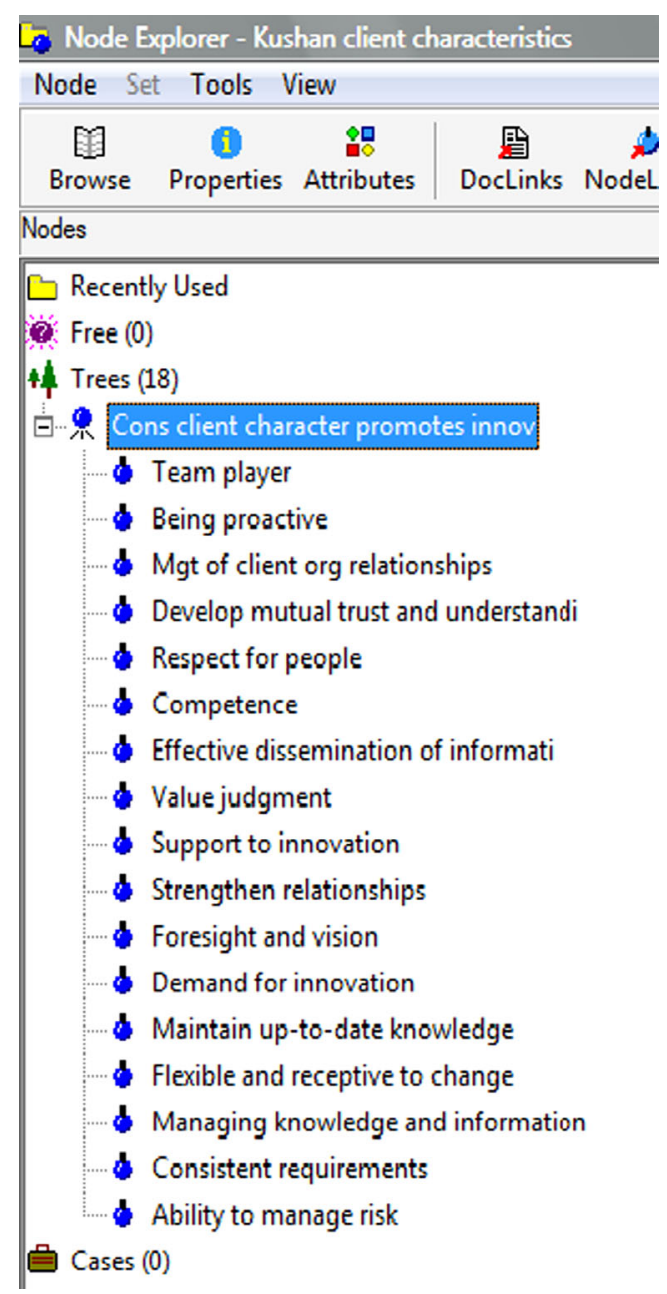

Figure 1. NVivo structure representing the characteristics of client that promotes innovation

also acknowledged client's participation and further added, "they (client organisation) offered their own suggestions and possible improvements to what we had to offer". Even though the proactive involvement of the client affects overall success of innovation, its effect on holding the team together was identified as most important by all the interviewees. Clients' proactive involvement results in speedy approval process that had a positive effect on the project progress. Further, the proactive nature of client influenced the effective decision making that supports innovation within the constriction project. However, it was noted that overloading the client with other commitments has reduced the involvement of the client to the project. For example, construction manager of project $\mathrm{Y}$ observed that the client had been overloaded with work to be effectively proactive, which was also confirmed by the client who stated: 
CI 11,4

388

Figure 2.

Decision explorer diagram to represent client characteristic
Fi Decision Explorer - Demonstration version - restricted license

File Edit Property View List Analysis Control Window Help

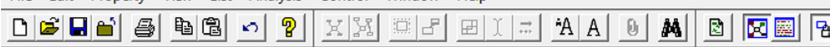

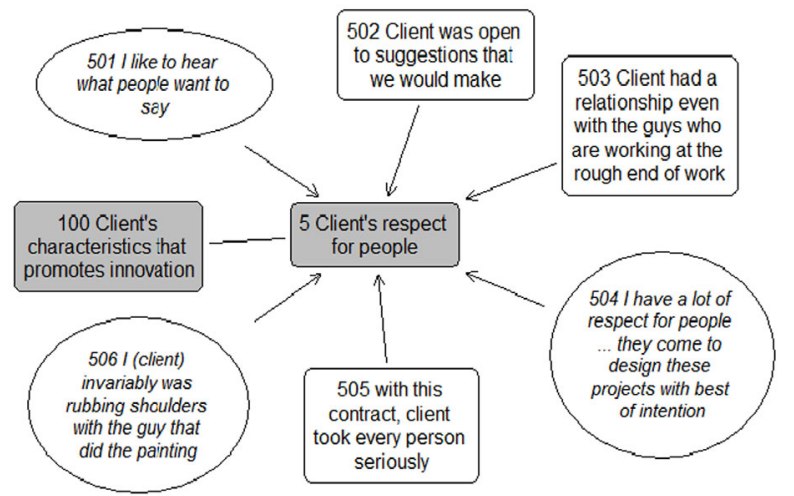

\begin{tabular}{|c|c|c|}
\hline Test & Aspect & Action taken \\
\hline \multirow[t]{4}{*}{ Reliability } & Participant error & $\begin{array}{l}\text { Case selection from a data rich partnering environment } \\
\text { Selection of correct interviewees by analysing the } \\
\text { information flow patterns and relationship held with the } \\
\text { client }\end{array}$ \\
\hline & Participant bias & $\begin{array}{l}\text { Selection of participants from various parties } \\
\text { (e.g. construction manager, client and contractor) to } \\
\text { minimise bias }\end{array}$ \\
\hline & Observer error & $\begin{array}{l}\text { Use of semi-structured interviews to understand } \\
\text { perspective from the participant's point of view }\end{array}$ \\
\hline & Observer bias & Verification of transcripts by the interviewees \\
\hline Construct validity & $\begin{array}{l}\text { Multiple sources } \\
\text { of evidence }\end{array}$ & $\begin{array}{l}\text { Collection of data from both client and other participants } \\
\text { to understand both perspectives } \\
\text { Document reference }\end{array}$ \\
\hline \multirow[t]{2}{*}{ Internal validity } & Pattern matching & $\begin{array}{l}\text { Generated conclusions supported by literature where } \\
\text { applicable }\end{array}$ \\
\hline & $\begin{array}{l}\text { Explanation } \\
\text { building }\end{array}$ & $\begin{array}{l}\text { Establishment of link between client's behaviour and the } \\
\text { innovation process with the support of the direct } \\
\text { quotations from the interviewees }\end{array}$ \\
\hline $\begin{array}{l}\text { Descriptive and } \\
\text { interpretive validity }\end{array}$ & & $\begin{array}{l}\text { Direct quotation from the interviewees used in case } \\
\text { description and concept building to ensure accurate } \\
\text { description and to ensure transparency of } \\
\text { interpretations }\end{array}$ \\
\hline External validity & & Undertook cross-case analysis \\
\hline
\end{tabular}

Table II.

Quality criterion used for the study
Ilike to be out on site a bit more, to keep a bit more control of some issues and to keep up with what was going on, however, time wise I don't have time to do that because of other responsibilities.

Desirability for the client's positive influence is also observed in studies done in other sectors. For example, a study conducted on development of information technology 
systems revealed that there is a mutual configuration process happening between users/clients and designers throughout the design process (Mackay et al., 2000). The importance of the client's involvement for construction innovation is also highlighted by Nam and Tatum (1997). The study revealed a strong correlation between the client's commitment to the innovation and the innovation success of the project.

\section{Client as a team player}

The client's ability and willingness to be a team player has been a contributory factor towards construction innovation in projects. Client's presence created a sense of joint responsibility for the actions taken by the team and has inspired the team members to actively involve with the innovative ideas. "I feel more comfortable going out of this organisation (client organisation) and doing what the Project Manager or the Construction Manger did" commented project X client highlighting the level of team spirit he had. "We make our decisions as a team. Everybody in that team buys into that. The client, the Managing Agent, specialists we don't move forward until all of us buy into our proposals" added project manager of project X. He further added, "we wouldn't have got this far without the client's support" emphasising the inspiration got from the client's participation. The study also revealed that misunderstanding between team members and client has damaged the team spirit and thereby hampering construction innovation. This finding coincides with Martin et al. (1999) who observed that breakdowns in the innovation process are due to a lack of participation by the client.

\section{Management of client organisations' internal relationships}

The ability of the client to obtain timely support from other important inter-organisational divisions of client organisation is one of the factors that had a direct influence on the success of the project. Getting the involvement of other divisions of the client organisation such as technical division has allowed the project managers to liaise directly with the relevant people for speedy results. "They (members of client organisation) are there to challenge our decisions", which assured nothing is overlooked said project X client. "I know few famous projects that have gone through haven't quite worked". Therefore, "there was an attempt to get other parts of the client organisation involved with the project from day one" project X client added.

\section{Develop mutual trust and understanding}

The empirical investigation revealed that the development of mutual understanding is important for the success of any project regardless of whether it is innovative or not. "[...] to be able to deal with very many different people is important for the development of mutual understanding between parties" claimed project Y client. Mutual trust and understanding can create relationships between individuals, which are crucial for teamwork in the construction project setting. Trust on the capabilities of technical stakeholders, empowered designers in the development of the innovative scheme. The trust and understanding developed within the team members proved to be an additional encouragement for the delivery team to be responsible for their work. Highlighting this, project manager of project X stated "client had trust in our designers [...] this encouraged them a lot when dealing with their work".

Literature also attests to the importance of mutual trust between clients and construction professionals (Ivory, 2004; Martin et al., 1999). Ivory (2004) suggests that
Construction innovation 
CI 11,4

390 the differences in types and levels of knowledge held by clients and construction professionals can hinder mutual understanding between parties which can be a considerable barrier for effective client collaboration in construction innovation. Furthermore, designers can potentially resist client interaction if a threat to the ownership of the design is felt. The consequences of damaged trust between client and professional parties are also established in studies in other sectors. One case, in the service sector, demonstrated how damaged trust can lead to the development of suspicion and the exclusion of the client from the design process which leads to consequences such as delays and sub optimal outcomes (Martin et al., 1999).

\section{Client's respect for people}

The client's respect for people had been identified as a main driving force for effective construction innovation. The clients' willingness to listen not only to other construction professionals but also to other skilled and unskilled workers was an incentive for the generation of new and innovative ideas. "Client had a relationship not only with myself, as the project manager, but also with the guys who are working at the rough end as well" said project manager of project X. Client also confirmed the project manager's statement. "I (client) invariably was rubbing shoulders with the guy that did the painting. It was not a question”. According to the project manager of project $Y$ :

I think best innovations often come from the most unlikely sources. They can be steel fixers, carpenters, labourers or whoever on site. They have really good ideas, but are scared to share them for the sake of being laughed at or they don't think it is genuine or they won't be taken seriously. Within the project we (the client and other professionals) took every person seriously.

Thus, giving proper respect to people can be highlighted as a championing behaviour for construction innovation. Similarly, findings of Slaughter (1991) identify users as an important source of innovation, which produce incremental innovation through learning by doing. Therefore, it is very rewarding to establish an environment where these incremental innovations or ideas are shared for the benefit of the whole project.

\section{Client's competence}

Client's competence is one of the strengths behind the effective participation in the construction innovation process. It was asserted that professional background, experience, expertise on the subject matters, up to date knowledge on the inside out of construction industry can unravel most of the complicated processes and procedures. "I can ask the right questions from people" declared project X client. "Through my engineering professional background I challenge (what was said by others)" he further added. These characteristics motivated the delivery team to ensure that all the design options were investigated in varying perspectives before selection of the optimum solution. Such capabilities of client motivate the team members when taking decisions and justifying alternative options related to innovative ideas.

The findings can be further strengthened by the study of Roger (2008) which highlights client's operating knowledge to interact with consultants and suppliers on the construction work can make innovative activities successful in large construction projects. Nam and Tatum (1997) also attribute innovation to the higher technical competency of respective clients. In their study, the client's technical competency became an enabler for the proactive involvement of the client in the innovation process. Other research has revealed that the professional parties share the responsibility 
of design with the client only when they perceive the client to be an expert (Ivory, 2004). Further, the study of Bougrain (2008) revealed the passive behaviour of the client due to lack of expertise of the problems contractors are dealing with.

\section{Effective dissemination of information}

Proper dissemination of the information into and the out of the team is an important activity that should be facilitated by the client for the success of construction innovation as such information flow directs project team to design and construct the project. Failure of client to adequately brief the team on the objectives of the project and other client initiatives can result in confusion, which will impact negatively on the innovation process. "I see a problem of communicating client's objectives to other team members [...] which resulted in not taking some critical actions required for the project" stated construction manager of project Y referring to lack of communication within the project.

\section{Client's value judgment}

One of the prominent characteristics of clients involved in the study that favoured innovation was their adequate understanding of value. The clients looked at the innovation as a value improvement process rather than a cost cutting measure and willing to pay extra for the innovative solution that minimised the impact on the traffic. Construction manager of project Y referred to instructions received from client, "client was saying that I am prepared to pay proper cost for experiments which would improve the reliability of the final solution." Further, because of the early consultation process, the designer was able to address buildability issues in the innovative solution at an early stage in the design. "Client was very actively involved with the value engineering process which is a main part of the innovation process in this project". Designers confirmed client's comprehension of the overall value of the project to promote innovation.

\section{Client's support to innovation}

The effective coordination mechanisms established by the client helped to raise the innovative culture among the team members. Early contractor involvement was a key instrument behind the innovation outcome. "I brought the interface between the client's side and the people actually carrying out the work then you get this dialog going whereby you start to understand, why things were done in a certain way. You get more familiar with the risks and the construction techniques" stated project X client. This provides shared responsibility, which is strength to promote construction innovation. Further, client's foresight and the intelligence to plan and support construction innovation in advance leads to successful innovation in construction projects. Initiating innovation reward scheme for the project has inspired the employees of the projects to continuously involved in innovative ideas. Such incentives were identified, by Rose (2005), as a tool to motivate people towards innovation.

\section{Strong relationships}

It was revealed from the study that, strong relationships with project members and other external stakeholders as a factor for successful innovation in construction projects. Project manager of project X appreciated the client's efforts to strengthen relationships by stating:

\section{Construction innovation}

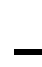


CI

11,4

392

[...] we are very lucky as the client actually fund these early consultations with specialist contractors who were able to convince the designers that new methods of working could actually solve this problem.

Relationships built between client and the rest of the project team can be strengthened by mutual trust and understanding, respect for people, and the client's proactive approach that will lead to highly satisfying achievements in innovation. The close relationships initiated by the client improved the mutual understanding and trust between team members that enabled flow of information through informal means that expedite the decision making related to innovation. However, client's passive approach to relationship building could affect the team spirit and could result in emergence of conflict and confusion on the team members that can have a negative impact on the process of the innovation.

The study of $\mathrm{Lu}$ (2008) also highlighted the importance of client's positive interaction with the team members of the projects, client's own organisation, and customers. Nam and Tatum (1997) identified the client as the base around which other parties communicate, collaborate, make important and innovative decisions and implement the project. Further, strong relationships lead to informal networks which are identified as being the most commonly used means of innovation diffusion (Larsen, 2005). Thus, ability to initiate strong relationship becomes a prerequisite for a client looking for innovation.

\section{Foresight and vision}

One of the characteristics highly appreciated by the respondents of the case studies was foresight and vision of the clients on construction innovation. Continuous search for innovative ideas and methods lead to discovery of new ways to "do things better". Client encouraged and funded investigative actions on critical issues related to innovative ideas to ensure smooth progress of work and to minimise possible confusions and unexpected surprises at actual implementation of the innovation. "Client had an open mind and was also willing to go and explore other avenues and he allowed us to do that" added project manager of project X. Client's vision on innovation provides clear guidance for the project team to proceed with innovative ideas. "You got to think long term as well. What will happen to this route anyway? Is it going to be widened, do we need to spend this money" project X client highlighted the importance of foresight which helped to improve the feasibility of the design. This forward thinking nature and long-term view of the client facilitated the development of the innovative solution that addresses the current problem with consideration on possible future requirements.

\section{Demand for innovation}

Client's demand for innovation became one of the main drivers for innovation in these case study projects. The client's demand for innovative ideas to cater the requirements of the projects forced the designers to think "out of the box" to design innovative solutions. Project Y sub-contractor admitted that "effectively project team had found a way of doing it thus we were forced to do it by the client". Project Y client confirmed the opinion of the sub-contractor stating "[...] directly or indirectly they (the innovation unit) are asking for innovation and they are demanding it [...] it has a positive effect on the outcome". Further, project Y client explained why the client organisation is so concerned about innovation. "(we need innovation) to respond to modern changes 
in technology, changes in requirements where more people are friendly people drive organisations, we need to respond to what people need". The positive effects of demand coincide with the findings of Gardiner and Rothwell (1985) who have conducted an extensive study on development of Boeing 747 aircraft. Client's demand pushed the supplier beyond existing boundaries to develop a radically innovative design in commercial aviation. However, the empirical investigation indicated the importance of the client to manage demand with proper interaction with team members. If not the demanding client can create a hostile atmosphere where designers will take a defensive position that is less conductive for the client participation as elaborated by Mackay et al. (2000).

\section{Maintain up-to-date knowledge about project development}

Client's willingness to be kept well informed and to have up-to-date knowledge about the developments of the project rendered positive results for construction innovation. In the opinion of project manager X, the advantage of a well-informed client is the significant reduction of approval times thus speeding up the innovative activities. "What the client didn't need to do is go away and then try and understand what we were asking. Because he understood straight away" said project manager X. Project X designer also confirmed the opinion of project manager stating "the client was so well up to speed about what we were doing. So they are able to sign things off very quickly for us". Further, the well informed client managed information dissemination within the stakeholders successfully.

\section{Flexible and receptive to change}

Extreme regulations are identified as one of the limits of construction innovation (Blayse and Manley, 2004; Veshosky, 1998; Pries and Janszen, 1995). The case study results also revealed extensive regulations as hindrances for effective implementation of innovative ideas thus acknowledging the importance to have some degree of flexibility on the part of the client in relation to the standard procedures, regulations, and client organisation bureaucracy. Project X designer said:

[...] we get a better idea as the scheme develops which means your initial technical submission and the final outcome is quite different, therefore we made late technical submissions but at all times we were keeping the client organisation fully informed about what we were doing and why we were doing it.

Such flexible approaches of the client to the standard processes and procedures without endangering the organisations goals and safety criteria, etc. expedited the innovation process.

\section{Managing knowledge and information}

The effectiveness of the information management had consequences on the innovation process. The importance of the information for the innovation has been highlighted by previous researchers. In a study conducted by Veshosky (1998), project managers identified lack of information as a barrier for innovation highlighting its importance. "The documents (specifications working methods, etc.) on that scheme should be on a shelf somewhere [...] I think that (secure knowledge) can be driven by the clients" commented project Y sub-contractor highlighting the importance of good practice and knowledge transfer from the innovative construction projects to future projects.

\section{Construction innovation}

393 
CI

11,4

394

\section{Consistent requirements}

The study reveals the importance of establishing reasonably firm goals and priorities by the client at an early stage of the project. Literature also identifies firm specifications and a clear introduction to innovation goals as enabling factors that can increase the possibility of innovation (Ling, 2003; Gardiner and Rothwell, 1985). Even though acceptance of change is a prerequisite for innovation, continuous change throughout the project can cause negative impacts on innovation. The failure of the client to establish basic criterion at the initial stage can lead to delays in project completion due to rework. Construction manager of project $Y$ observed "this client is ever changing. There is a new initiative every week [...] This can cause frustration”. Sub-contractor of Project $Y$ also added:

[...] if something changes (client's rules and procedures) you should at least apply it to the next scheme, you should not apply different rules to the scheme you are working on.

As such, ever-changing nature of client requirements can cause frustration and can undermine the other priorities of the project such as time and cost.

\section{Ability to manage risk}

Any decision arrived at regarding innovation involves a proportion of risk. Accordingly, client's ability and willingness to accept and manage risk was identified as a factor that encourages innovative process. Project manager of project $\mathrm{X}$ complimented the client:

[...] what we did in project X, was a quite bold piece of work to do [...] It's potentially quite a lot of abortive costs which designers spent that eventually we may feel we can't deliver.

The study of Manley et al. (2005) suggests that public sector clients are often risk averse thus not willing to support innovative construction ideas that are more costly or that could provide unknown results. In this respect, proper analysis and discussions about the risk involved with innovative activities is found to be important. By doing so, the impact of risks can be properly managed to an acceptable level; similar to the finding of the empirical investigation on willingness to take the risk.

\section{Conclusion}

The study extended the current understanding of the championing characteristics of construction client that promotes construction innovation. It was argued at the beginning of the paper that lack of understanding about client characteristics that promote innovation could lead to not practicing them effectively. The client characteristics identified from this study therefore, widen the knowledge base of the client to successfully engage in construction innovation. It is evident that client's personal characteristics such as competence, value judgment on innovation, foresight and vision towards innovation promotion, self-motivation, flexibility and receptiveness to change and receptiveness to risks had an empowering effect on the client's roles thus influencing all aspects of innovation. The characteristics like client's ability to be a team player, ability to initiate fruitful relationships to promote mutual trust and understanding, respect for people, proactive involvement, effective communication, dissemination, and coordination of work has influenced to minimise the fragmentation of the different stakeholders involved within the construction projects and had a good bearing on team dynamics to positively influence innovative activities. 
Client's demand for an outcome beyond existing capabilities also motivates the project team in engaging in innovative activities. Hence, the aforementioned findings of this study contribute to knowledge by providing better guidance for a client who is looking to promote innovation within construction projects.

As mentioned in previous research work of seminal authors such as Lim and Ofori (2007), Gann and Salter (2000), Egan (1998) and Latham (1994) reports, the aforementioned championing characteristics identified from the study further strengthen the significance attached to construction clients in promoting innovation. The championing characteristics identified form the study indicate a correlation between client's activities and construction innovation as suggested by the seminal work of Nam and Tatum (1997). Further, the study echoes the findings of previous studies that extreme demand can cause frustration that can diminish the morale and motivation of individual project members.

Productive innovation process is a function of positive team work and positive client's own action. However, success of the team work is highly influenced by the client characteristics. As evident from the study, the ability to initiate strong relationships among team members driving the whole team towards the innovative solutions was identified as a championing behaviour of a client who is in pursuit of innovation. Thus, construction client with the championing characteristics identified in the study can be attributed as an innovation promoting agent within the construction industry.

Reliability of the study was ensured by mitigating participant error, participant bias, observer error and observer bias. Validity of the study was maintained by using multiple sources of evidence, carrying out pattern matching between primary and secondary data, use of direct quotations and undertaking cross-case analysis between the selected projects. The study was based around a large public sector client and both case studies were selected from one particular type of procurement arrangement, that is partnering contracts. The selection of the cases from a data rich partnering source enabled the discovery of useful information which leads to the achievement of the aim and objectives of the study. However, this purposive selection can have implications on generalisability as there can be practical constraints in applying it to other procurement arrangements such as design and build or traditional tendering. In addition to that, case studies were selected from projects where innovation was present. Accordingly, further studies can be done for private sectors clients and those who are working under other procurement methods, and for construction projects that lack innovation to investigate the client characteristics that had lead to lack of innovation within the projects.

\section{References}

Ball, M. (1988), Rebuilding Construction, Routledge, London.

Barrett, P. and Sexton, M.G. (1999), "The transformation of 'out-of-industry' knowledge into construction industry wisdom", paper presented at Workshop on Linking Construction Research and Innovation to Research and Innovation in Other sectors, Construction Research and Innovation Strategy Panel, London.

Bernard, H.R. (2000), Social Research Methods: Qualitative and Quantitative Approaches, Sage, Thousand Oaks, CA.

Blayse, A.M. and Manley, K. (2004), "Key influences on construction innovation", Construction Innovation, Vol. 4 No. 3, pp. 143-54.
Construction innovation

395 
CI

11,4

396
Bougrain, F. (2008), "The role of the client in building site innovation", in Brandon, P.S. and Lu, S.L. (Eds), Clients Driving Innovation, Blackwell, Oxford.

Bresnen, M. and Marshall, N. (2000), "Partnering in construction: a critical review of issues, problems and dilemmas", Construction Management and Economics, Vol. 18 No. 2, pp. 229-37.

Bresnen, M. and Marshall, N. (2001), "Understanding the diffusion and application of new management ideas in construction", Engineering, Construction and Architectural Management, Vol. 8 Nos 5/6, pp. 335-45.

Brightman, J. (2003), "Mapping methods for qualitative data structuring (QDS)", Methodological Issues and Practices Using QSR NVivo and NUD *IST, Institute of Education, London, 8-9 May.

Brightman, J. (2004), “Cognitive mapping - theory and practice”, Value Magazine, June, pp. 18-22.

Department for Business Enterprise and Regulatory Reform (2007), "Draft strategy for sustainable construction”, Consultation Paper, Department for Business, Enterprise and Regulatory Reform, London, July.

DIUS (2008), Innovation Nation, Department for Innovation, Universities and Skills, London.

Dulaimi, M.F. (2008), "Driving innovation in construction: conceptual model of client leadership behaviour", in Brandon, P.S. and Lu, S.L. (Eds), Clients Driving Innovation, Blackwell, Oxford.

Dulaimi, M.H., Nepal, M.P. and Park, M. (2005), "A hierarchical structural model of assessing innovation and project performance", Construction Management and Economics, Vol. 23 No. 6, pp. 565-77.

Eden, C. (1992), "On the nature of cognitive maps", Journal of Management Studies, Vol. 29 No. 3, pp. 261-5.

Egan, J. (1998), Rethinking Construction: Report from the Construction Task Force, Department of the Environment, Transport and Regions, London.

Egbu, C. (2008), “Clients' roles and contributions to innovations in the construction industry: when giants learn to dance", in Brandon, P. and Lu, S.L (Eds), Clients Driving Innovation, Blackwell, Oxford.

Egemen, M. and Mohamed, A.N. (2006), “Clients' needs, wants and expectations from contractors and approach to the concept of repetitive works in the Northern Cyprus construction market", Building and Environment, Vol. 41 No. 5, pp. 602-14.

Eisenhardt, K.M. (2002), "Building theories from case study research", in Huberman, A.M. and Miles, M.B. (Eds), Qualitative Researcher's Companion, Sage, Thousand Oaks, CA.

Fairclough, J. (2002), Rethinking Construction Innovation and Research, A Review of Government: $R \& D$ Policies and Practices, Department of Trade and Industry, London.

Fortune, C. and Setiawan, S. (2005), "Partnering practice and the delivery of construction projects for housing associations in the UK", Engineering, Construction and Architectural Management, Vol. 12 No. 2, pp. 181-93.

Fullerton, J. and West, M.A. (1996), "Consultant and client - working together", Journal of Managerial Psychology, Vol. 11 No. 6, pp. 40-9.

Gann, D.M. and Salter, A.J. (2000), "Innovation in project-based, service-enhanced firms: the construction of complex products and systems", Research Policy, Vol.29 Nos 7/8, pp. 955-72.

Gardiner, P. and Rothwell, R. (1985), “Tough customers: good designs”, Design Studies, Vol. 6 No. 1, pp. 7-17.

Green, S.D. (1999), "The missing arguments of lean construction", Construction Management and Economics, Vol. 17 No. 2, pp. 133-7. 
Harty, C. (2005), "Innovation in construction: a sociology of technology approach", Building Research and Information, Vol. 33 No. 6, pp. 512-22.

Hillebrandt, P.M. (2000), Economic Theory and the Construction Industry, Macmillan, London.

Himes, P.E. (1995), "Partnering in the construction process: the method for the 1990s", Facilities, Vol. 13 No. 6, pp. 13-15.

Ivory, C. (2004), "Client, user and architect interactions in construction: implications for analysing innovative outcomes from user-producer interactions in projects", Technology Analysis \& Strategic Management, Vol. 16 No. 4, pp. 495-508.

Ivory, C. (2005), "The cult of customer responsiveness: is design innovation the price of a client-focused construction industry?", Construction Management an Economics, Vol. 23 No. 8, pp. 861-70.

Kumaraswamy, M. and Dulaimi, M. (2001), "Empowering innovative improvements through creative construction procurement", Engineering, Construction and Architectural Management, Vol. 8 Nos 5/6, pp. 325-34.

Larsen, G.D. (2005), "Horses for courses: relating innovation diffusion concepts to the stages of the diffusion process", Construction Management and Economics, Vol. 23 No. 8, pp. 787-92.

Latham, M. (1994), Constructing the Team, HMSO, London.

Lim, J.N. and Ofori, G. (2007), "Classification of innovation for strategic decision making in construction businesses", Construction Management and Economics, Vol. 25 No. 9, pp. 963-78.

Ling, F.Y.Y. (2003), "Managing the implementation of construction innovations", Construction Management and Economics, Vol. 21 No. 6, pp. 635-49.

Lu, S.L. (2008), "The role of the client in the innovation process of small construction professional service firms", in Brandon, P.S. and Lu, S.L. (Eds), Clients Driving Innovation, Blackwell, Oxford.

Mackay, H., Carne, C., Beynon-Davies, P. and Tudhope, D. (2000), "Reconfiguring the user: using rapid application development”, Social Studies of Science, Vol. 30 No. 5, pp. 737-57.

Maklan, S., Knox, S. and Ryals, L. (2008), "New trends in innovation and customer relationship management", International Journal of Market Research, Vol. 50 No. 2, pp. 221-40.

Manley, K. (2006), "The innovation competence of repeat public sector clients in the Australian construction industry", Construction Management and Economics, Vol. 24 No. 12, pp. 1295-305.

Manley, K., Blayse, A. and Swainston, M. (2005), "Implementing innovation on commercial building projects on Australia”, in Brown, K., Hampson, K. and Brandon, P. (Eds), Client Driving Construction Innovation: Mapping the Terrain, CRC Construction Innovation, Brisbane.

Martin, C.R., Horn, D.A. and Schultz, A.M. (1999), "The business-to-business customer in the service innovation process", European Journal of Innovation Management, Vol. 2 No. 2, pp. 55-62.

Nam, C.H. and Tatum, C.B. (1997), "Leaders and champions for construction innovation", Construction Management and Economics, Vol. 15 No. 3, pp. 259-70.

Pries, F. and Janszen, F. (1995), "Innovation in the construction industry: the dominant role of the environment", Construction Management and Economics, Vol. 13 No. 1, pp. 43-51.

Reichstein, T., Salter, A.J. and Gann, D.M. (2005), "Last among equals: a comparison of innovation in construction, services and manufacturing in the UK", Construction Management and Economics, Vol. 23 No. 6, pp. 631-44.

\section{Construction} innovation 
CI

11,4

398
Roger, M. (2008), “Clients as innovation drivers in large engineering projects”, in Brandon, P.S. and Lu, S.L. (Eds), Clients Driving Innovation, Blackwell, Oxford.

Rose, T.A.M.K. (2005), “A conceptual framework to investigate the optimisation of financial incentive mechanisms in construction projects", CIB W92/T23/W107, International Symposium on Procurement Systems: The Impact of Cultural Differences and Systems on Construction Performance, CIB, Las Vegas, NV, 7-10 February.

Seaden, G. (2003), "Strategic decisions and innovation in construction firms", Construction Management and Economics, Vol. 21 No. 6, pp. 603-12.

Seaden, G. and Manseau, A. (2001), "Public policy and construction innovation", Building Research and Information, Vol. 29 No. 3, pp. 182-96.

Sexton, M.G. and Barrett, P.S. (2003a), "A literature synthesis of innovation in small construction firms: insights, ambiguities and questions", Construction Management and Economics, 21 September, pp. 613-22 (special issue on Innovation in Construction).

Sexton, M.G. and Barrett, P.S. (2003b), "Appropriate innovation in small construction firms", Construction Management and Economics, 21 September, pp. 623-33 (special issue on Innovation in Construction).

Silverman, D. (2001), Interpreting Quantitative Data, 2nd ed., Sage, London.

Slaughter, S.E. (1991), "Innovation and learning during implementation: a comparison of user and manufacturer innovations", Research Policy, Vol. 22, pp. 81-95.

Veshosky, D. (1998), "Managing innovation information in engineering and construction firms", Journal of Management in Engineering, Vol. 124 No. 1, pp. 58-66.

Whyte, J. (2003), "Innovation and users: virtual reality in the construction sector", Construction Management and Economics, Vol. 21, May, pp. 561-72.

Yin, K. (2003), Case Study Research: Design and Methods, 3rd ed., Sage, Thousand Oaks, CA.

\section{Further reading}

Sexton, M., Abbott, C. and Lu, S.L. (2008), "Challenging the illusion of the all power client's role in driving innovation”, in Brandon, P.S. and Lu, S.L. (Eds), Clients Driving Innovation, Blackwell, Oxford.

\section{Corresponding author}

Udayangani Kulatunga can be contacted at: u.kulatunga@salford.ac.uk

To purchase reprints of this article please e-mail: reprints@emeraldinsight.com Or visit our web site for further details: www.emeraldinsight.com/reprints 